\title{
Cretaceous faunas and events, northern Eromanga Basin, Queensland
}

Queensland Museum, PO Box 3300, South Brisbane, QLD 4101, Australia. E-mail: Alex.cook@qm.qld.gov.au

The stratigraphy, sedimentary history and paleontology of the northern Eromanga Basin are reviewed in the light of extensive field effort, searching for Cretaceous vertebrate fossils, in particular dinosaurs. Prolonged non-marine deposition throughout the Jurassic was followed by Lower Cretaceous marine incursions which extended to the late Albian. Whilst biostratigraphy is underpinned by microfloral assemblages there are three distinct marine faunas preserved from the late Aptian, early middle Albian and late Albian. Effective regression caused by sediment oversupply in the latest Albian heralded the final phase of non-marine deposition in the Eromanga Basin which continued into the Cenomanian. A distinct floral assemblage is accompanied by a modest fossil vertebrate assemblage.

\section{Introduction}

The Eromanga Basin is a large, continental basin which, with the interconnected Surat Basin in the southeast, and Carpentaria Basin to the north, forms the Great Australian Basin (GAB) that further connects with the Laura Basin in the northeast and the ClarenceMoreton, Nambour and Maryborough basins in the southeast to form the Great Australian Superbasin and dominate the continental geology of northeastern Australia (Figure 1). Each basin of the GAB contains a near flat-lying Jurassic to Cretaceous sequence which records basin subsidence and the varying roles of sea-level change and sediment supply throughout the GAB's history. Geological summaries are available for the Carpentaria Basin (McConachie et al., 1997), the Surat Basin (Green 1997), the southern and central Eromanga Basin (Gray et al. 2002) and the northern Eromanga Basin (Green et al. 1992).

The Eromanga Basin extends from South Australia and New South Wales into northern Queensland. It is separated from the Carpentaria Basin by the Euroka Arch, a basement high with structural drape, and by a similar feature, the Nebine Ridge, from the Surat Basin. The northern Eromanga Basin overlies the late Paleozoic Galilee Basin, and Paleozoic basement, and onlaps Proterozoic provinces to the north and northwest.

Lithostratigraphy of the Eromanga Basin has been elucidated by regional mapping and by water and petroleum exploration wells. In the north of the basin, these wells are less common, but have been supplemented by government sponsored stratigraphic wells.

The stratigraphy for the northern Eromanga is summarised in Figure 2. Identified depositional phases include Early Jurassic dominantly coarse-grained fluvial deposition, followed by more subdued Mid-Upper Jurassic-Lower Cretaceous fluvio-lacustrine sedimentation. In the Lower Cretaceous a succession of marine transgressions and regressions resulted in a series of shallow marine, varyingly fossiliferous deposits, the youngest of which is late Albian. Concomitant volcanism to the east which had been active since the Jurassic was more prevalent in the Lower Cretaceous, and was dominated by the Whitsunday Island Volcanic Province (Bryan et

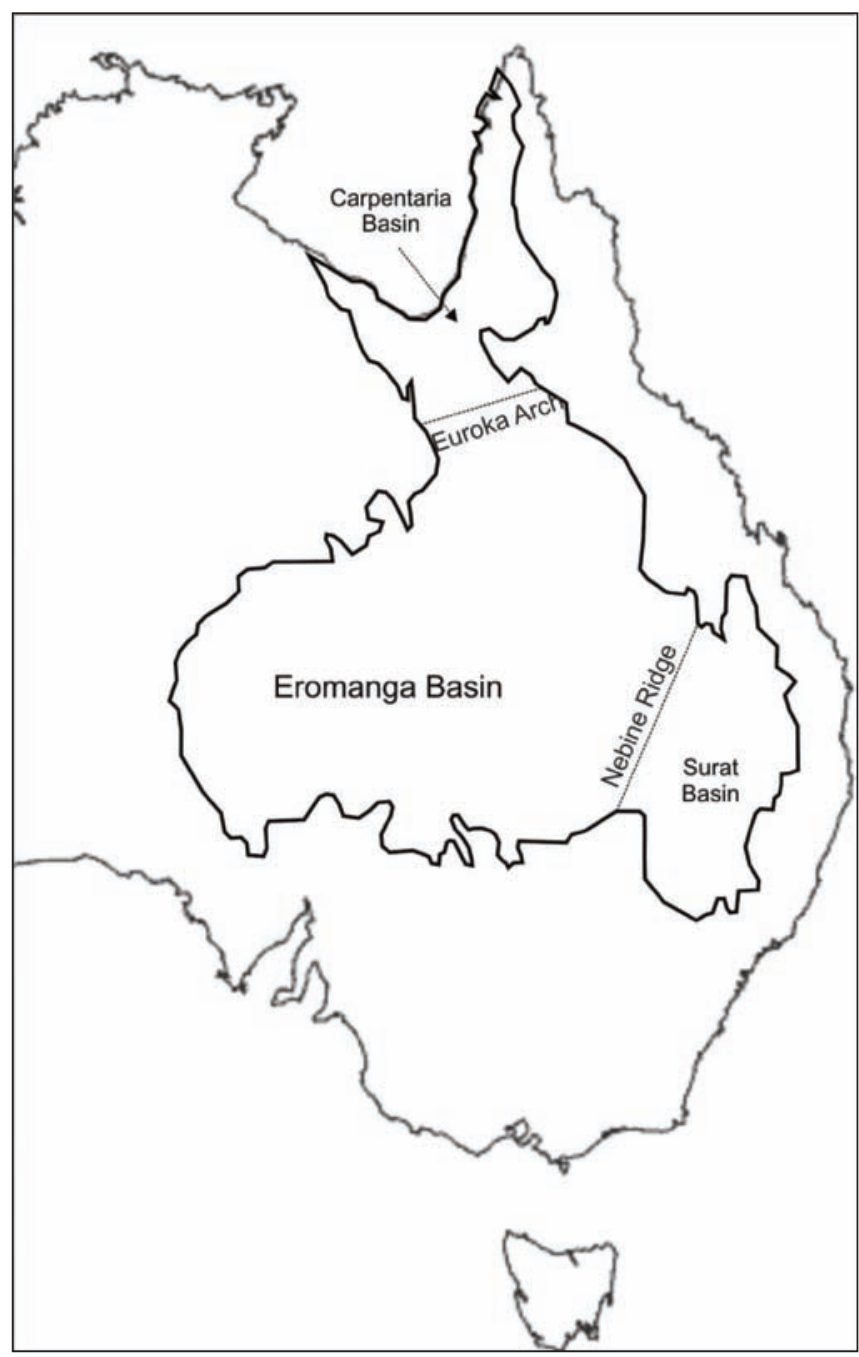

Figure 1 The Great Australian Basin in northeastern Australia. 


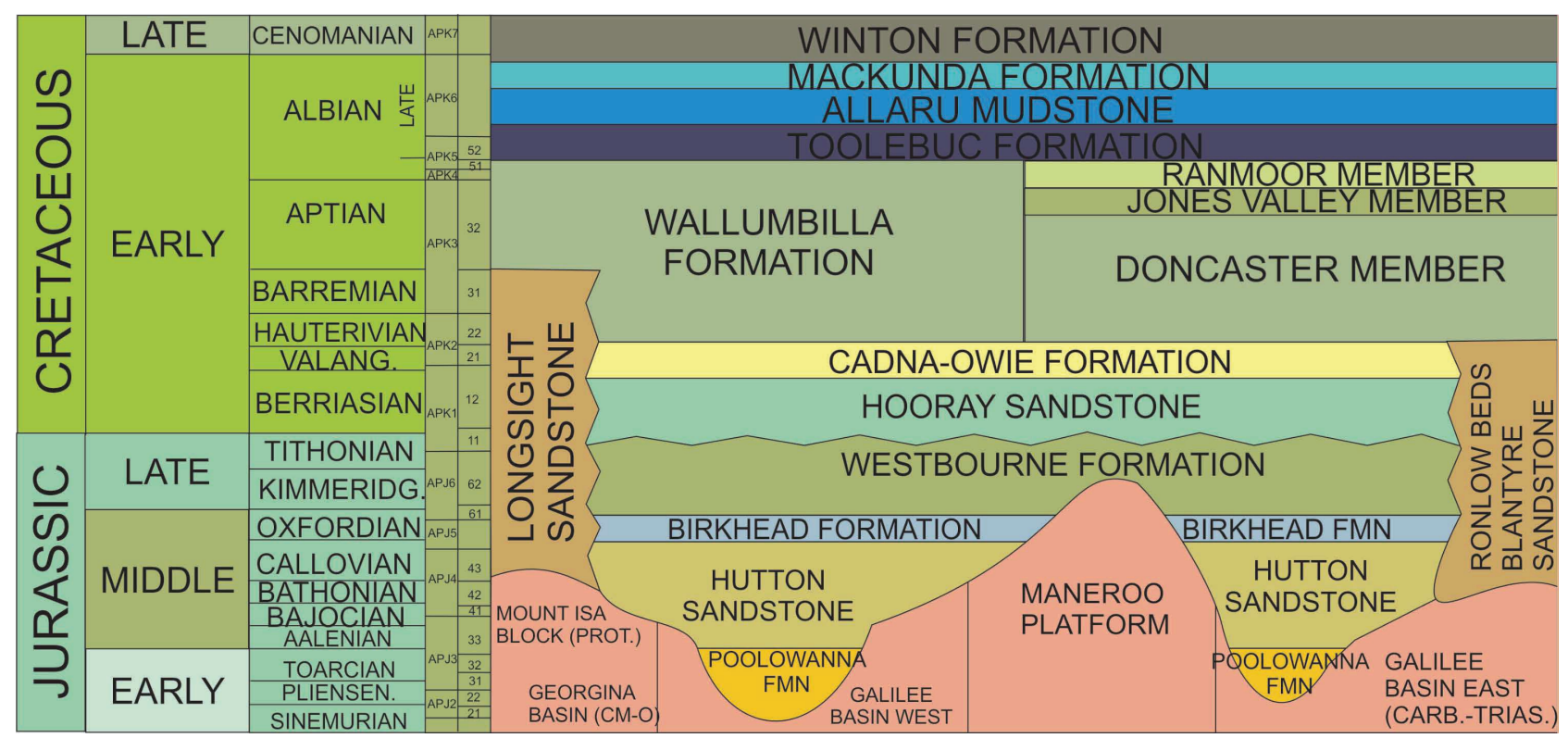

Figure 2 Stratigraphy of the northern Eromanga Basin modified after Green et al. (1992) and Gray et al. (2002).

al., 2000), situated near the east coast. Volcanogenic sediment oversupply peaked in the late Albian to Cenomanian, to the extent that it caused effective regression with nonmarine deposition. The globally recognised Cenomanian sea level rise did not manifest within the Great Australian Basin. Non-marine sedimentation ceased in the Upper Cretaceous, and was followed by three cycles of deep weathering and erosion which extended until at least the Miocene, with accompanying tectonic flexure along pre-existing structures.

\section{Principal stratigraphic divisions}

Jurassic stratigraphy in the northern Eromanga Basin comprises a basal Jurassic coarse fluviatile unit, now referred to the Poolowanna Formation. This is overlain by the extensive coarse-grained fluvial, Hutton Sandstone and subsequent Birkhead Formation which was deposited in fluvio-lacustrine settings with strong supply of volcanogenic detritus from the east. The Adori Sandstone overlies this and represents braided fluvial systems. The fluviolacustrine Westbourne Formation, and overlying fluvial Hooray Sandstone are overlain by the Cadna-owie Formation which represents transition to marginal marine conditions during Valanginian-Barremian transgression. Rapid continued transgression in the Aptian resulted in deposition of the Doncaster Member of the Wallumbilla Formation, a widespread unit which represents maximum flooding of the continent. Effective but subdued regression-transgression in the early middle Albian is represented by deposition of the Ranmoor Member of the Wallumbilla Formation. Transgression renewed rapidly in the late Albian with deposition of the Toolebuc Formation, representing maximum flooding within a partly anoxic restricted basin, resulting in a mixed limestone-oil shale unit which is isochronous across the basin. The unit correlates with the global Oceanic anoxic event (OAE) 1c. Renewal of sediment supply from the east prompted deposition of the Allaru Mudstone and overlying Mackunda Formation which are late Albian regressive units. Sediment supply exceeded subsidence choking the basin during this time, and this continued into the Cenomanian, which is represented by an entirely non-marine sedimentary package.
Biostratigraphy within the basin is primarily controlled by rich palynofloras (Dettmann and Playford 1969; Price 1997), but also by ammonites, foraminifera and locally recognised molluscan assemblages (Day, 1969).

Palynomoprh stratigraphy developed for continental Australia has been summarised for the southern Eromanga and Surat basins by Price (1997), and Draper (2002). Marine and marginal marine units span Australian Palynological units APK2.1 to APK6, with the upper nonmarine Winton Formation belonging within APK7 (Figure 2). Dinocyst zones of Helby et al. (1987) indicate the Cadna-owie Formation extending to include an unnamed zone, and the basal $O$. operculata zone, with the youngest marine units in the $P$. ludbrookiae zone (see Branagan (2012) for more on Nell Ludbrook). Price (1997) replaced zones with dinocyst units, the upper Cadna-owie in ADK17, and the Mackunda Formation within ADK22. Foraminifera have been evaluated in some units (Haig, 1979; Haig and Lynch, 1993) and some investigations of nannofossils have been undertaken by Shafik (1985). The relation of palynology to local and global cyclicity has been addressed by Burger (1986), who could not identify all Jurassic global cycles within the Eromanga and Surat basins.

\section{Fossil Assemblages}

Three principal marine fossil assemblages and an upper nonmarine fossil faunal assemblage within the northern Eromanga Basin correspond to the late Aptian, early middle Albian, late Albian and late Albian to Cenomanian, respectively.

\section{Late Aptian assemblage}

The Late Aptian marine incursion that brought maximum flooding of the continent, is represented by the Doncaster Member of the Wallumbilla Formation across the GAB, with equivalents in the Laura Basin. The diverse and distinctive fauna of the Doncaster Member that was locally named the Roma Fauna (Whitehouse, 1926) contains ammonites (Etheridge, 1880, 1892, 1909; Whitehouse, 1926; Day, 1974), predominantly heteromorphs including Tropaeum, 

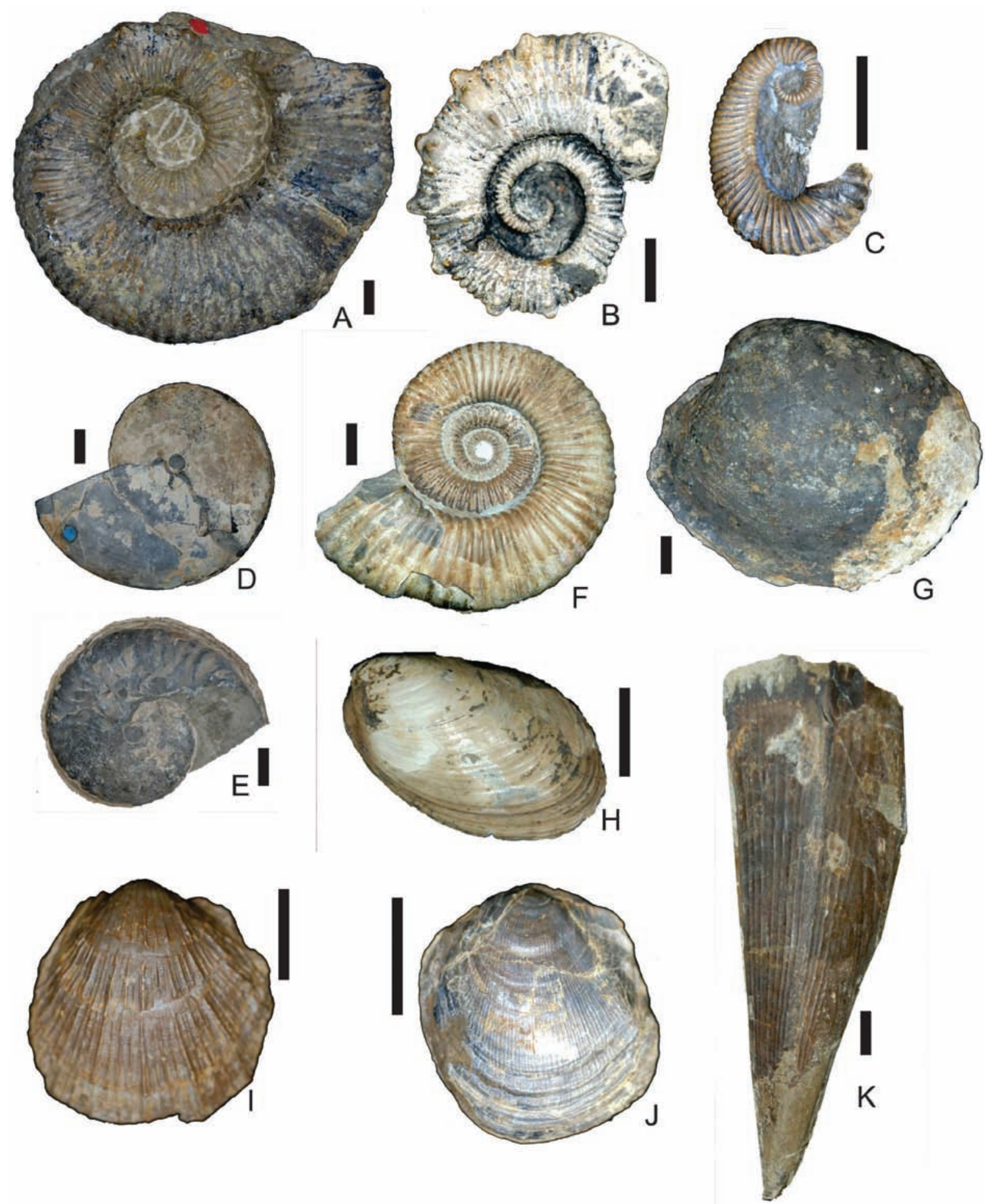

Figure 3 Typical Late Aptian assemblage of macrofossils from the Doncaster Member, Wallumbilla Formation. (A). Tropaeum undatum; $(B)$. Australiceras irregulare; $(C)$. Tonohamites taylori; $(D)$. Aconeceras sp.; $(E)$. Sanmartinoceras olene; $(F)$. Australiceras jacki; (G). Fissilunula clarkei; (H). Eyrena palmerensis; (I). Maccoyella barkleyi; (J). Pseudavicula anomala; $(\mathrm{K})$. Pinna $s p$. $($ Scale bar $=2 \mathrm{~cm})$.

Australiceras, Tonohamites, Toxoceratoides, Sanmartinoceras and Aconeceras. The more than 30 species of bivalves include locally stratigraphically important Maccoyella barklyi, Fissilunula clarkei, Pseudavicula anomala and Eyrena palmerensis. In addition Panopaea, Pinna, scaphopods, the crinoid Isocrinus australis and gastropods are locally abundant. Purisiphonia clarkei is the only known sponge (Jell et al., 2011). Kronosaurus queenslandicus, undescribed plesiosaurs and rare ichthyosaurs are known from the unit. In the northern Eromanga Basin algal build-ups resembling stromatolites form elongate ridges of tens of metres scale, or isolated domal, conical and lamellar forms. Commonly, build-ups are found around large marine reptile specimens. This is surprising given the high latitude position of the basin during the late Aptian, glendonites and dropstones elsewhere in the basin during this time. 


\section{Early Middle Albian assemblage}

The macrofaunas of the Ranmoor Member are depauperate, reflecting the its subdued outcrop patterns. Fauna recovered from the Ranmoor Member includes the ammonites Beudanticeras flindersi, Falciferella sp. and several undescribed species. Bivalves such as Aucellina and Inoceramus are in smaller numbers than in the overlying Toolebuc Formation.

\section{Late Albian assemblages (Figure 4)}

The Toolebuc Formation, Allaru Mudstone and overlying Mackunda Formation have similar, but not identical faunas, which include vertebrates, ammonites, bivalves and other molluscs. The Toolebuc Formation is dominated by a restricted benthic assemblage of Inoceramus sutherlandi and Aucellina hughendensis, but a diverse nektic assemblage of fishes, marine reptiles and molluscs, including large ichthyosaur skeletons (Wade, 1990) of Platypterigius australis, the pliosaur Kronosaurus queenslandicus, elasmosaurs and at least one species of polycotylid, three turtles, being the giant Cratochelone, known from a single specimen, the common Notochelone and Bouliachelys Kear and Lee (2006). Abundant fish fossils include amiids, aspidorhynchids, chimaeroids, lamnids, dipnoans, (Lees, 1986, 1990, Lees and Bartholomai, 1987, Bartholomai, 1969, 2004, 2008). Ammonites include Beudanticeras flindersi, Myloceras spp., Labeceras spp., Idanoceras, and possibly Worthoceras with the nautiloid Eutrephoceras hendersoni also common. The teuthids Trachyteuthis willisi, Meunsterella tonii and Boreopeltis soniae were described from the Toolebuc Formation and overlying basal Allaru Mudstone (Wade, 1993). Abundant belemnites have received scant

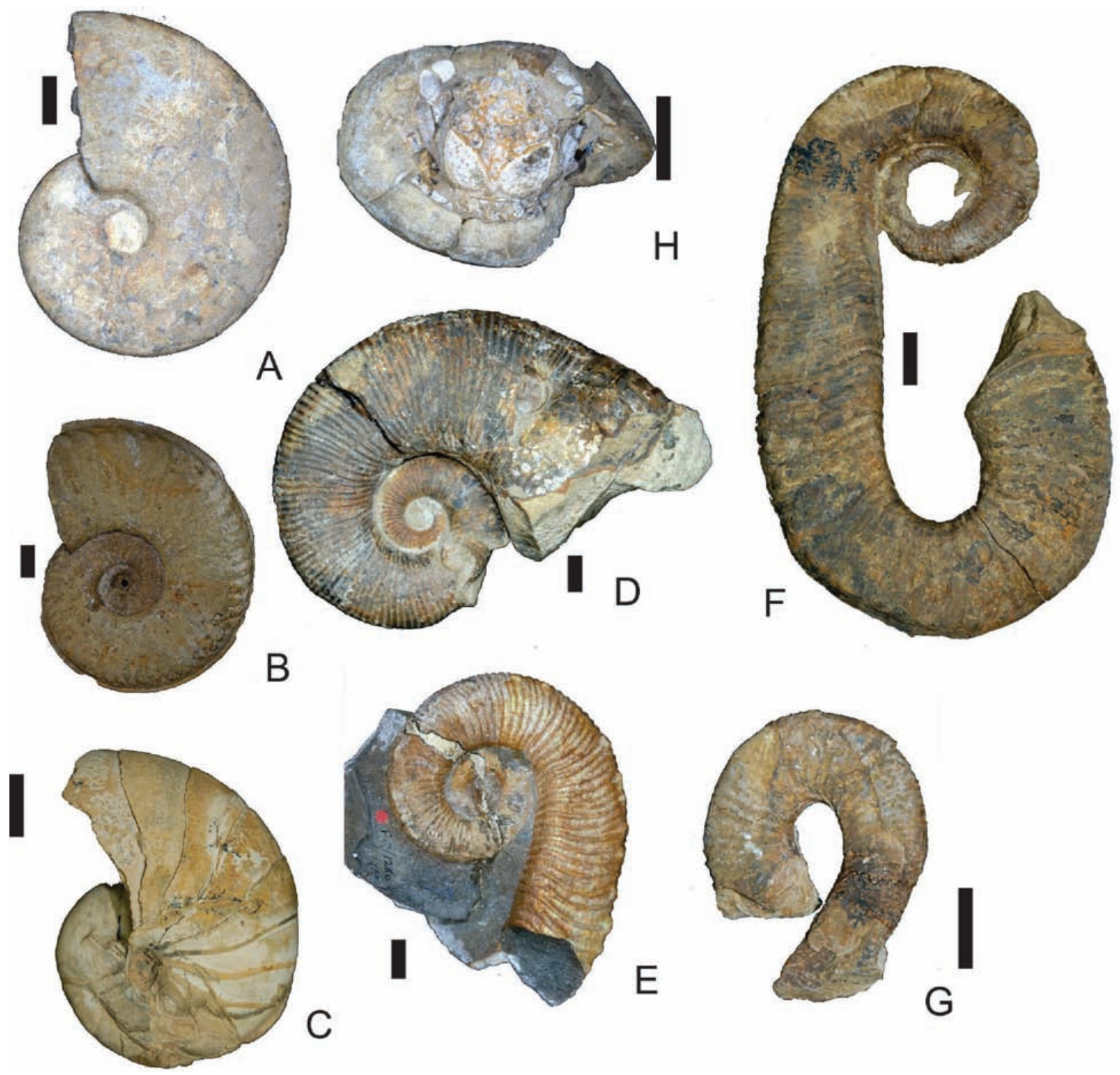

Figure 4 Typical Late Albian assemblage of macrofossils from the northern Eromanga Basin. (A) Beudanticeras flindersi; (B) Goodhallites goodhalli; (C) Eutrephoceras hendersoni; (D) Myloceras ammonoides; $(E)$ Myloceras intermedium; $(F)$ Myloceras auritulum; $(G)$ Labeceras compressum; (H) Homolopsis etheridgei (Scale bar $=2 \mathrm{~cm}$ ). 


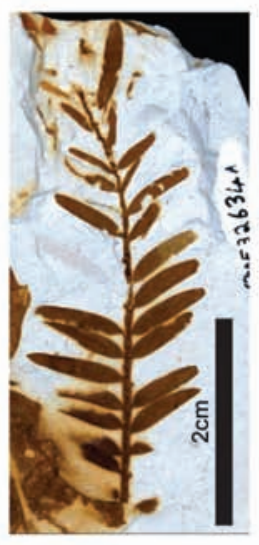

A
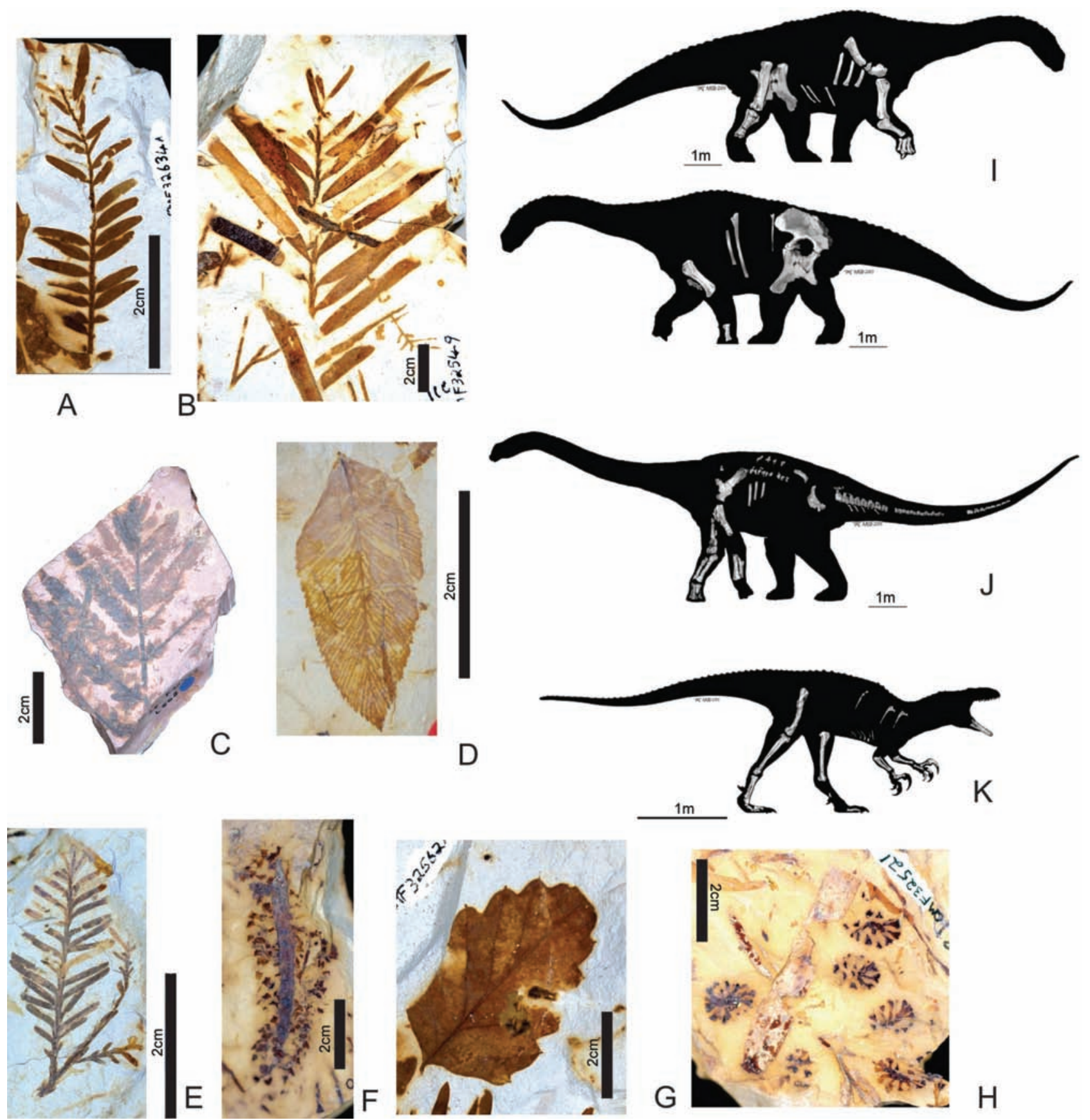

$\mathrm{H}$

Figure 5 Winton Formation floral assemblage and dinosaurs. (A) Araucaria $c f$. A. mesozoica; (B) Araucaria $c f$. A. mesozoica; (C) Cladophlebis sp.; (D) Phyllopteroides meclymontae; $(E)$ Conifer foliage; $(F)$ Male sporangiate cone; (G) Angiosperm leaf; (H) Small cones $c$. Austrosequioa wintonesis; (I) Diamantinasaurus matildae; (J) Australovenator wintonensis; (K) Wintonotitan wattsi (Dinosaur silhouettes after Hocknull et al. (2009)).

attention. Terrestrial and associated faunal elements have also been recovered from the Toolebuc Formation including the dinosaurs Minmi sp., and Muttaburrasaurus langdoni, a small number of pterosaur elements, the bird Nanatius eos and sauropod bones.

The Allaru Mudstone has yielded common ammonites, Beudanticeras, Myloceras spp. and Labeceras spp. with lesser Idanoceras (Henderson and McKenzie, 2002), and Goodhallites goodhalli (Henderson and Kennedy, 2002), and a small fauna of undescribed micromorphs. Bivalve diversity is still low in the unit with Inoceramus dominant, alongside Aucellina. Crustacea are locally abundant. Rare ophiuroids and monasterid seastars are known. A single faviid coral recovered from the unit (Jell et al., 2011) attests to relatively warm conditions during deposition even at mid-high latitudes. There is some disparity between faunas in the lower parts of the unit compared to the upper, supported by seismic evidence of a break in the lower Allaru Mudstone, but this faunal disparity has yet to be investigated fully.

The Mackunda Formation is the uppermost marine unit and has a diverse benthic and nektic fauna. Benthic elements include bivalves with the ubiquitous Inoceramus and Aucellina accompanying Maccoyella rookwoodensis, Panopaea, Acesta, Tatella, and solemyiids among other taxa. Belemnites are abundant, but ammonites 
are much less common. Small naticiid and higher spired gastropods are common in some of the shell beds which are common in the formation. Teleosts are less common, but shark's teeth are abundant.

\section{Winton terrestrial assemblage}

The Winton Formation contains a diverse and abundant fossil macroflora (Peters and Christophel, 1978; Dettmann et al., 1992, 2009; McLoughlin et al., 1995; Pole and Douglas, 1999; Pole, 2000a, b; McLoughlin et al., 2010; Dettmann and Clifford, 2000; Clifford and Dettmann, 2005) including conifers, ferns, cycadophytes, angiosperms and ginkgos. Undescribed insects are known in collections. A modest dinosaur fauna (Figure 5); Coombs and Molnar, 1981; Hocknull et al., 2009) includes the genera Australovenator, Wintonotitan, and Diamantinasaurus. Australovenator is a mediumsized allosauroid, neovenatorid taxon, whilst Diamantinasaurus is a lithostotian titanosaurian and Wintonotitan a titanisauriform. More discoveries of dinosaurian material in 2010 and 2011 extend the diversity. Other elements include crocodylians (Salisbury et al., 2006), fishes, lungfish (Kemp, 1991), a dolichosaur, turtles, and pterosaur remains. Of outstanding importance is the dinosaurian ichnofauna which is exemplified by the Dinosaur Stampede National Monument, Lark Quarry (Thulborn and Wade, 1979, 1984). The dinosaurian and marine reptile finds support an economically important tourism industry in the northern Eromanga Basin.

\section{Acknowledgements}

E.D. McKenzie, the late Mary Wade and the many welcoming landowners in western Queensland are thanked for their assistance over many years. Peter Jell and Mary Dettmann are thanked for helpful reviews.

\section{References}

Bartholomai, A., 1969, The lower Cretaceous elopoid fish Pachyrhizodus marathonensis (Etheridge Jnr.), in Campbell, K.S.W. (ed), Stratigraphy and palaeontology: Essays in Honour of Dorothy Hill: Australian National University Press, Canberra, pp. 249-263.

Bartholomai, A., 2004, The large aspidorhynchid fish Richmondichthys sweeti (Etheridge Jr and Smith Woodward 1891) from Albian marine deposits of Queensland Australia: Queensland Museum, Memoirs, v. 49, pp. 521536.

Bartholomai, A., 2008, Lower Cretaceous Chimaeroids (Chondrichthyes: Holocephali) from the Great Artesian Basin, Australia: Queensland Museum, Memoirs, v. 52, pp. 49-56.

Branagan, D.F., 2012, Fleshing out the landscape: two centuries of Australia's geological heroes: Episodes (this volume)

Bryan, S. E., Ewart, A., Stephens, C.J., Parianos,J. and Downes, P.J., 2000, The Whitsunday Volcanic Province, central Queensland, Australia: Lithological and stratigraphic investigations of a silicic-dominated large igneous province: Journal of Volcanology and Geothermal Research, v. 99, pp. 55-78.

Burger, D., 1986, Palynology, cyclic sedimentation, and palaeoenvironments in the late Mesozoic of the Eromanga Basin, in Gravestock, D.I., Moore, P.S. and Pitt, G.M. (eds), Contributions to the Geology and Hydrocarbon Potential of the Eromanga Basin: Geological Society of Australia, Special Publication 12, pp. 53-70.

Clifford, H.T. and Dettmann, M.E., 2005, First record from Australia of the Cretaceous fern genus Tempskya and the description of a new species, $T$. judithae: Review of Palaeobotany and Palynology, v. 134, pp. 71-84.
Coombs, W.P. and Molnar, R.E., 1981, Sauropoda (Reptilia, Saurischia) from the Cretaceous of Queensland: Queensland Museum, Memoirs, v. 20, pp. 351-372.

Day, R.W., 1969, The Lower Cretaceous of the Great Artesian Basin. in Campbell, K.S.W. (ed), Stratigraphy and Palaeontology: Essays in Honour of Dorothy Hill: Australian National University Press, Canberra, pp. 140 173.

Day, R.W., 1974, Aptian ammonites from the Eromanga and Surat Basins, Queensland: Geological Survey of Queensland, Publication 360, pp. 119.

Dettmann, M.E. and Clifford, H.T., 2000, Gemmae of the Marchantiales from the Winton Formation (mid-Cretaceous), Eromanga Basin, Queensland: Queensland Museum, Memoirs, v. 45, pp. 285-292.

Dettmann, M.E. and Playford, G., 1969, Palynology of the Australian Cretaceous: a review. in Campbell, K.S.W. (ed), Stratigraphy and Palaeontology: Essays in Honour of Dorothy Hill: Australian National University Press, Canberra, pp. 174-210.

Dettmann, M.E., Molnar, R.E., Douglas, J.G., Burger, D., Fielding, C., Clifford, H.T.,Francis, J., Jell, P., Rich, T., Wade, M., Rich, P.V., Pledge, N., Kemp, A. and Rozefelds, A., 1992, Australian Cretaceous terrestrial Dettmann faunas and floras: biostratigraphic and biogeographic implications: Cretaceous Research, v. 13, pp. 207-262.

Dettmann, M.E., Clifford, H.T. and Peters, M., 2009, Lovellea wintonensis gen. et sp. nov.-Early Cretaceous (late Albian), anatomically preserved, angiospermous flowers and fruits from the Winton Formation, western Queensland, Australia: Cretaceous Research, v. 30, pp. 339-355.

Etheridge, R. Jr., 1880, On a collection of fossils from the Bowen River Coalfield: Proceedings of the Royal Physical Society of Edinburgh, v. 5, pp. 263-328.

Etheridge, R. Jr., 1892, Chapter 32. The organic remains of the Rolling Downs Formation (Lower Cretaceous) in Jack, R.L. and Etheridge, R.Jr. (eds), The Geology and Palaeontology of Queensland and New Guinea: Publication of the Geological Survey of Queensland, pp. 434-510.

Etheridge, R. Jr., 1909, Lower Cretaceous fossils from the sources of the Barcoo, Ward and Nive Rivers, south central Queensland. Part II ? Cephalopoda: Australian Museum, Records, v. 7, pp. 135-165, 235240.

Draper, J.J. (ed), 2002, Geology of the Cooper and Eromanga Basins, Queensland: Queensland Minerals and Energy Review Series, Queensland Department of Natural Resources and Mines, Brisbane.

Gray, A.R.G., McKillop, M. and McKellar, J.L., 2002, Eromanga Basin Stratigraphy in Draper, J.J. (ed), Geology of the Cooper and Eromanga Basins, Queensland. Queensland Minerals and Energy Review Series, Queensland Department of Natural Resources and Mines, pp. 30-56.

Green, P.M. (ed), 1997, The Surat and Bowen Basins, south-east Queensland: Queensland Minerals and Energy Review Series, Queensland Department of Mines and Energy, Brisbane.

Green, P.M., Hawkins, P.J., Carmichael, D.C., Brain, T.J., Smith, R.J., Quarantotto, P. Genn, D.L.P., Hoffmann, K.L., McKellar, J.L., John, B.H. and Shield, C.J., 1992, An assessment of the hydrocarbon potential of the northern Eromanga Basin, Queensland: Queensland Government Mining Journal, v. 93, pp. 25-41.

Haig, D.W., 1979, Cretaceous foraminiferal biostratigraphy of Queensland: Alcheringa, v. 3, pp. 171-187.

Haig, D.W. and Lynch, D.A., 1993, A late early Albian marine transgressive pulse over northeastern Australia, precursor to epeiric basin anoxia: foraminiferal evidence: Marine Micropalaeontology, v. 23, pp. 311-362.

Helby, R.J., Morgan, R. and Partridge, A.D., 1987, A palynological zonation of the Australian Mesozoic: Association of Australasian Palaeontologists, Memoirs, v. 4, pp. 1-94.

Henderson, R.A. and Kennedy, W.J., 2002, Occurrence of Goodhallites goodhalli J. Sowerby (Ammonoidea) in the Eromanga Basin: an index species for the late Albian (Cretaceous): Alcheringa, v. 26, pp. 223-237.

Henderson, R.A. and McKenzie, E.D., 2002, Idanoceras, a new heteromorph ammonite genus from the late Albian of Eastern Australia: Journal of Paleontology, v. 76, pp. 906-909. 
Hocknull, S.A., White, M.A., Tischler, T.R., Cook, A.G., Calleja, N.D, Sloan, T. and Elliott, D.A., 2009, New mid-Cretaceous (latest Albian) dinosaurs from Winton, Queensland, Australia: PLoS ONE, v. 4, pp. 3-51.

Jell, J.S., Cook, A.G. and Jell, P.A., 2011, Australian Cretaceous Cnidaria and Porifera: Alcheringa, v. 35, pp. 241-284.

Kear, B.P. and Lee, M.S.Y., 2006, A primitive protostegid from Australia and early sea turtle evolution: Biology Letters, v. 2, pp. 116-119.

Kemp, A., 1991, Australian Cenozoic and Mesozoic lungfish, in Rich, P.V., Monahan, J., Baird, R.F. and Rich, T.H. (eds), The vertebrate palaeontology of Australasia, $2^{\text {nd }}$ ed.: Monash University Publications Committee and Pioneer Design Studio, Clayton, pp. 465-489.

Lees, T., 1986, A new chimaeroid Ptyktoptychion tayyo gen. et sp. nov. (Pisces: Holocephali) from the marine Cretaceous of Queensland: Alcheringa, v. 10 , pp. $187-193$.

Lees, T., 1990, A probable neoteleost, Dugaldia emmilta gen. et sp. nov., from the Lower Cretaceous of Queensland, Australia: Queensland Museum, Memoirs, v. 28, pp. 79-88.

Lees, T. and Bartholomai, A., 1987, Study of a Lower Cretaceous Actinopterygian (Class Pisces) Cooyoo australis from Queensland, Australia: Queensland Museum, Memoirs, v. 25, pp. 177-192.

McConachie, B.M., Dunster, J.N., Wellman, P., Denaro, T.J., Pain, C.F., Habermehl, M.A. and Draper, J.J., 1997, Carpentaria Lowlands and Gulf of Carpentaria Regions, in Bain, J.H.C. and Draper, J.J. (eds), North Queensland Geology. AGSO Bulletin, v. 240/ Queensland Geology, v. 9, pp. 365-397.

McLoughlin, S., Drinnan, A.N. and Rozefelds, A.C., 1995, A Cenomanian flora from the Winton Formation, Eromanga Basin, Queensland, Australia: Queensland Museum, Memoirs, v. 38, pp. 273-313.

McLoughlin, S., Pott, C. and Elliott, D., 2010, The Winton Formation flora (Albian-Cenomanian, Eromanga Basin): implications for vascular plant diversification and decline in the Australian Cretaceous: Alcheringa, v. 35, pp. 1-21.

Peters, M.D. and Christophel, D.C., 1978, Austrosequoia wintonensis a new taxodiaceous cone from Queensland, Australia: Canadian Journal of

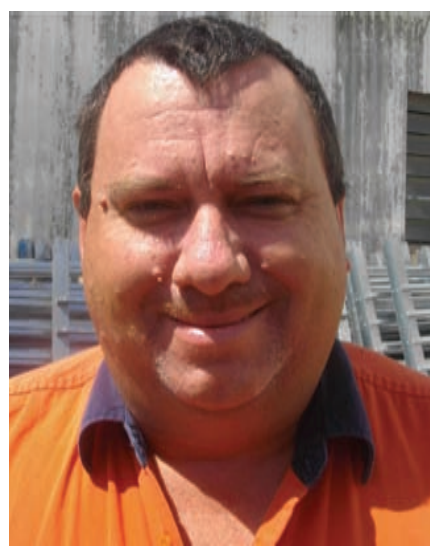

Alex Cook is Senior Curator of Geosciences at the Queensland Museum where he has worked since 1992. His diverse geological interests include Paleozoic molluscs, particularly gastropods, trace fossils and the general Phanerozoic geology of northern Australia. He has worked extensively within the Great Artesian Basin.
Botany, v. 56, pp. 3119-3128.

Pole, M., 2000a, Dicotyledonous leaf macrofossils from the latest Albianearliest Cenomanian of the Eromanga Basin, Queensland, Australia: Paleontological Research, v. 4, pp. 39-52.

Pole, M.S., 2000b, Latest Albian-earliest Cenomanian monocotyledonous leaves from Australia: Botanical Journal of the Linnean Society, v. 129, pp. $177-186$

Pole, M.S. and Douglas, J.G., 1999, Bennettitales, Cycadales and Ginkgoales from the mid Cretaceous of the Eromanga Basin, Queensland, Australia: Cretaceous Research, v. 20, pp. 523-538.

Price, P.L., 1997, Permian to Jurassic palynostratigraphic nomenclature of the Bowen and Surat Basins, in Green, P.M. (ed), The Surat and Bowen Basins south-east Queensland: Queensland Minerals and Energy Review Series, Queensland Department of Mines and Energy, Brisbane, pp. 137178

Salisbury, S. W., Molnar, R.E. and Frey, E., 2006, The origin of modern crocodyliforms: new evidence from the Cretaceous of Australia: Proceedings of the Royal Society B, v. 273, pp. 2439-2448.

Shafik, S., 1985, Calcareous nannofossils from the Toolebuc Formation, Eromanga Basin, Australia: BMR Journal of Geology and Geophysics, v. 9, pp. 171-181.

Thulborn, R.A. and Wade, M., 1979, Dinosaur stampede in the Cretaceous of Queensland: Lethaia, v. 12, pp. 275-279.

Thulborn, R.A. and Wade, M., 1984, Dinosaur trackways in the Winton Formation (mid-Cretaceous) of Queensland: Queensland Museum, Memoirs, v. 21, pp. 413-518.

Wade, M., 1990, A review of the Australian longipinnate ichthyosaur Platypterygius (Ichthyosauria, Ichthyopterygia): Queensland Museum, Memoirs, v. 28, pp. 115-137.

Wade, M., 1993, New Kelaenida and Vampyromorpha: Cretaceous squid from Queensland: Association of Australasian Palaeontologists, Memoirs, v. 15 , pp. 353-374.

Whitehouse, F.W., 1926, The Cretaceous Ammonoidea of eastern Australia: Queensland Museum, Memoirs, v. 8, pp. 195-242. 